\title{
Comments
}

\section{CONGRESSIONAL AUTHORITY TO RESTRICT THE USE OF LITERACY TESTS}

During the current session of Congress several bills have been introduced dealing with discrimination and the right to vote. These bills would prohibit barring any person from exercising the franchise because of his failure to satisfy any literacy or educational test if that person has completed six grades of education and has not been adjudged an incompetent. One of the bills, Senate Bill 2750, ${ }^{1}$ introduced by Senators Mansfield and Dirksen, has the backing of the Administration and may well become law. The proposal is limited to federal elections, while S. 480, the other main bill under consideration, encompasses state and local elections as well.

These proposals were mspired by the 1961 report of the United States Commission on Civil Rights. The Commission made five voting recommendations. ${ }^{2}$ One of these, unanimously endorsed by the six Commissioners, was:

That Congress enact legislation providing that in all elections in which, under State law, a "literacy" test, an "understanding" or "interpretation" test, or an "educational" test is administered to determine the qualifications of electors, it shall be sufficient for qualification that the elector have completed at least six grades of formal education. ${ }^{3}$

It is this recommendation that serves as the basis for the bills.

1 The identical bill was introduced in the House of Representatives by Emanuel Celler (D.N.Y.), the Chairman of the House Judiciary Committee. H.R. 10034, 87th Cong., 2d Sess. (1962).

2 For the Commission's recommendations see, 1 UntTed States Conmission on Civil Rigris 1961 REPORT 139-42 (1961) [hereinafter cited as 1961 CIVII Rigris RepoRT]. The one non-unaninous proposal of the Commission called upon Congress to declare all voting quabifications for either state or federal elections invalid except those relating to age, residence, confinement, or criminal conviction. The two dissenters, Robert G. Storey and Robert S. Rankin, felt the recommendation to be both unconstitutional and unwise since it would upset the established federal-state relationship involving voting qualifications. 1961 CrvIL RIGETs REPORT 140-41.

This proposal has been embodied in S. 2979, introduced by Senator Keating (R.N.Y.) for himself and a number of other Senators. In seeming contradiction, the bill also contains a hiteracy test restriction similar to that in S. 480 and S. 2750 . If the intent was to allow hiteracy tests in addition to qualifications as to age, residence, confinement, and criminal conviction, while making a sixth grade education sufficient to satisfy such tests, the bill poorly conveys this intent. If the purpose was to set forth the Commission's first recommendation in full, the hiteracy test section was unnecessary and, even more, confusing.

S. 2979 also embodies two other Commission recommendations. The first is a proposed amendinent to subsection (b) of 71 Stat. 637 (1957), 42 U.S.C. \& 1971 (1958), which prohibits interference by threats or coercion with the right to vote in federal elections. The amendment broadens the prohibition to include interference with this right by either arbitrary action or arbitrary inaction. S. 2979, 87th Cong., 2d Sess. $\$ 4$ (1962). Secondly, the bill directs the Bureau of the Census to compile comprehensive information and statistics on the number of registered voters and the number who have voted in each state, by race, color, and national origin. S. 2979, 87th Cong., 2d Sess. § 5 (1962).

31961 Crvil Rughts Report 141. 


\section{THE PROPOSALS}

The Mansfield-Dirksen bill begins with the following legislative findings: ${ }^{4}$ (1) That it is essential to our form of government that all qualified citizens have the opportunity to participate in the choice of elected officials; (2) that the right to vote in federal elections should be maintained free from discrimination and other corrupt influences; (3) that literacy and other tests have been used to effect arbitrary and unreasonable denials of the right to vote which existing statutes are inadequate to prevent; (4) that education in the United States is such that persons who have completed six primary grades in school cannot reasonably be denied the franchise on the grounds of illiteracy or lack of sufficient intelligence; and (5) that there is sufficient information available in Spanish to enable Spanish speaking citizens to intelligently exercise the franchise so that excluding these citizens from voting because of a lack of proficiency in English is unreasonable.

In light of these findings the bill would amend subsection (b) of 42 U.S.C. section 1971, which forbids any person from intimidating or coercing, or attempting to intimidate or coerce, any other person from voting as he may choose in any federal election. ${ }^{6}$ The bill would add a prohibition against depriving a person of the right to vote by

(1) the application to any person of standards or procedures more stringent than are applied to others similarly situated and

(2) the denial to any person otherwise qualified by law of the right to vote on account of his performance in any examination, whether for literacy or otherwise, if such other person has not been adjudged incompetent and has completed the sixth primary grade of any public school or accredited private school in any State or territory, the District of Columbia, or the Commonwealth of Puerto Rico.7

The Attorney General is empowered by subsection (c) ${ }^{8}$ of 42 U.S.C. section 1971

4 S. 2750, 87th Cong., 2d Sess. § 1 (1962).

5 The Civil Rights Commission received several complaints regarding the application to Puerto Ricans of the New York literacy requirement (N.Y. Consr. art. 2, §1, (ability to read and write English)). 1961 CIVII RIGHTS REPORT 18. The apparent intent of this legislative finding is to make clear that the enactment of this bill would prohibit the application of such a test to those Spanish speaking people who have completed the sixth grade, either in Puerto Rico or the United States. In Los Angeles there are a large number of Mexican-Americans who could be barred from registering because of their inability to read the Constitution in English. See Car. Const. art. II, $\S 1$. For the status of literacy tests in all states see Note, 31 Notre DanIE LAw. 251 (1956).

6 No person, whether acting under color of law or otherwise, shall intimidate, threaten, coerce, or attempt to intimidate, threaten, or coerce any other person for the purpose of interfering with the right of such other person to vote or to vote as he may choose, or of causing such other person to vote for, or not to vote for, any candidate for ... [federal office] at any general, special, or primary election held solely or in part for the purpose of selecting or electing any such candidate.

71 Stat. 637 (1957), 42 U.S.C. \$ 1971(b) (1958).

7 S. 2750,87 th Cong., 2 d Sess. $\$ 2$ (1962).

8 Whenever any person has engaged or there are reasonable grounds to behieve that any person is about to engage in any act or practice which would deprive any other person of any right or privilege secured by subsection (a) or (b) of this section, the Attorney General may institute for the United States, or in the name of the United States, a civil action or other proper proceeding for preventive relief ....

74 Stat. 90 (1960), 42 U.S.C. $\$ 1971$ (c) (Supp. II, 1961). 
to bring suit to prevent a violation of subsection (b) and this power would be extended to the proposed amendment.

Senate Bill 480, introduced by Senator Javits for a bi-partisan group of Senators, is substantially the same. It begins by expressing the fundamental necessity of the right to vote in a democratic society and then finds the present laws inadequate to prevent this right from being arbitrarily denied on the basis of race or color through the device of literacy tests. ${ }^{9} \mathrm{~A}$ finding is made that the high caliber of American education results in the reasonable expectancy that any person having completed six grades of schooling will be literate, so that a test denying to such person the right to vote is arbitrary and unreasonable. This bill has no special section relating to Spanish speaking citizens. ${ }^{10}$

Senate Bill 480 would amend subsection (a) of 42 U.S.C. section 1971, which now reads:

All citizens of the United States who are otherwise qualified by law to vote at any election by the people in any State, Territory, district, county, city, parisb, township, school district, municipality, or other territorial subdivision, shall be entitled and allowed to vote at all such elections, without distinction of race, color, or previous condition of servitude; any constitution, law, custom, usage, or regulation of any State or Territory, or by or under its authority, to the contrary notwithstanding.11

The amendment would add the right not to be subject to any "arbitrary or unreasonable test, standard, or practice with respect to literacy." This is further defined as meaning:

any requirement designed to determine hiteracy, comprehension, intelligence, or other test of education, knowledge, or understanding, in the case of any citizen who has not been adjudged an incompetent who has completed the sixth primary grade in a school accredited by any State or by the District of Columbia. 12

This bill would affect state and local elections as well as federal elections and would be enforceable through an injunctive suit brought by the Attorney General. ${ }^{13}$ Further, such a suit might result in the appointment of a voting referee in accordance with the 1960 Civil Rights Act. ${ }^{14}$ This would not be possible under the Administration's bill, since the appointment of referees is permissible only where subsection (a) of 42 U.S.C. section 1971 has been violated.

The Mansfield-Dirksen bill sets forth ${ }^{15}$ four separate constitutional powers its drafters rely upon to sustain the bill. These are: (1) article I, section 4 ; (2) section 5 of the fourteenth amendment; (3) section 2 of the fifteenth amendinent; and (4) the inherent power of Congress to protect the integrity of the federal electoral process. The purpose of this Comment is to investigate these constitutional powers to ascertain whether they will support either or both of the bills.

${ }^{8}$ S. 480, 87th Cong., 2d Sess. \$ 1 (1962).

10 This bill would not affect the application of the New York literacy test, see note 5 supra, in those instances where the Puerto Rican or other applicant has not finished the sixth grade within the United States.

1116 Stat. 140 (1870), 42 U.S.C. $\$ 1971$ (a) (1958).

12 S. 480, 87th Cong., 2d Sess. \& 2 (1962).

13 See note 8 supra.

1474 Stat. 90 (1960), 42 U.S.C. $\$ 1971$ (e), (Supp. II, 1961).

15 S. 2750, 87th Cong., 2d Sess. § 1(f) (1962). 
II

\section{THE CONSTITUTIONAI, BASES}

\section{A. Article I}

Article I, section 2 of the Constitution adopts as the qualifications necessary to vote for members of the House of Representatives the qualifications established by each state to vote for representatives to its most numerous legislative branch. ${ }^{10}$ The right to vote in senatorial elections is defined in identical terms by the seventeenth amendment. ${ }^{17}$ The power to establish voter qualifications was left to the states by the Constitutional Convention because of its inability to settle upon one standard. The requirements then enforced varied greatly, although almost all states required property holdings and nowhere were women allowed to vote. ${ }^{18}$ To have selected a uniform rule from the conflicting alternatives would have been difficult and would have generated opposition to the Constitution from those excluded who previously enjoyed the right to vote. ${ }^{19}$

Although the qualifications are prescribed by each state, Congress is not with out power under article I. Those who qualify under state law have a constitutional right to vote in congressional elections. ${ }^{20}$ Congress may protect this right against interference from both states and private individuals by any "necessary and proper" means. ${ }^{21}$ This protection may cover registration, primary elections, and the tabulation of balloting.

In addition, Congress has the ultimate power to regulate the times, places, and manner of holding congressional elections. Article I, section 4 initially places this responsibility with the states, ${ }^{22}$ which are authorized to:

10 "The House of Representatives shall be composed of members chosen every second year by the people of the several States, and the electors in each State shall have the qualifications requisite for electors of the nost numerous branch of the State legislature." U.S. CoNST. art. I, §2.

17 "The Senate of the United States shall be composed of two Senators from each State, elected by the people thereof, for six years; and each Senator shall have one vote. The elcctors in each State shall have the qualifications requisite for electors of the nost numerous branch of the State legislatures." U.S. ConST. amend. XVII.

18 Although the extent of suffrage prior to the Convention is disputable, both tbe Beardian and anti-Beardian historians agree that nearly all states imposed some property limitations on voting. Compare McGovney, American Suffrage Metoley 11-25 (1949), with R. Brown, Chardes Beard and the Constitution 61-72 (1956), and Witliamson, American Suthrage FROM PROPERTY TO DEMIOCRACY 1760-1860 1-137 (1960).

19 "The diversity of the standards then existing in the several states was the obstacle to agreement upon a single standard in national elections. The prevailing argument was that to adopt any standard for voting in national elections which would disquabify any person eligible to vote in state elections would arouse opposition to ratification of the Constitution." McGovNEx, american Suffrage Mediey 29 (1949). See also R. Brown, Charles Beard and tire ConstiTUTION 105-06 (1956).

20 United States v. Classic, 313 U.S. 299, 315 (1941); Ex parte Yarbrough, 110 U.S. 651, 663-64 (1884) ; United States v. Goldman, 25 Fed. Cas. 1350, 1353 (No. 15225) (C.C.D. La. 1878).

21 United States v. Classic, 313 U.S. 299, 315 (1941); Swafford v. Templeton, 185 U.S. 487, 491 (1902); Wiley v. Sinkler, 179 U.S. 58, 62-63 (1900) ; Ex parte Yarbrough, 110 U.S. 651, 661 (1884).

22 "The times, places, and manner of holding elections for Senators and Representatives, shall be prescribed in each State by the Legislature thereof; but the Congress may at any time by law make or alter such regulations, except as to the places of choosing Senators." U.S. Const. art. I, § 4 . 
provide a complete code for congressional elections, not only as to times and places, but in relation to notices, registration, supervision of voting, protection of voters, prevention of fraud and corrupt practices, counting of votes, duties of inspectors and canvassers, and making and publication of election returns; in short, to enact the numerous requirements as to procedure and safeguards which experience shows are necessary in order to enforce the fundamental right involved. ${ }^{23}$

Congress may, however, alter such state regulations or make its own. This power reserved to Congress is as extensive as that of the states, so that Congress may also "provide a complete code" for the conduct of congressional elections. When Congress does act, the states' regulations are invalidated only to the extent they are inconsistent with those of Congress. ${ }^{24}$

Congress has invoked both its authority to regulate the manner of holding congressional elections and its power to protect the right to vote in such elections in varied ways. It has required that votes be cast by printed or written ballot or by voting machine, ${ }^{25}$ and has established a uniform day for the holding of federal elections. $^{28}$ Under the Federal Corrupt Practices Act ${ }^{2 \pi}$ the expenditures of congressional candidates are limited ${ }^{28}$ and financial reports are required from political committees organized to influence the election of sucli candidates.

The most extensive congressional activity in the field of voting followed the passage of the fourteenth and fifteenth amendments. Legislation based upon article I penalized the use of force, threats, or other unlawful means to obstruct any person from performing any act necessary to qualify or from voting at any election. ${ }^{20}$ It also subjected those who registered or voted illegally to criminal prosecution. ${ }^{30}$ Further, conspiracies to prevent advocacy or support for any congres. sional or presidential candidate were prohibited. ${ }^{31}$ Criminal and civil sanctions were enacted penalizing election officers who violated either their state or federal duties in the conduct of congressional elections. ${ }^{32}$

In 1871 Congress imitiated a plan for the actual supervision of elections for members of the House of Representatives. ${ }^{33}$ Upon application by a specified num-

23 Smiley v. Holm, 285 U.S. 355, 366 (1932).

24 Id. at 367; Ex parte Siebold, 100 U.S. 371, 384-85 (1879).

2530 Stat. 836 (1899), 2 U.S.C. $\$ 9$ (1958).

26 The Tuesday after the first Monday in November is established as the day for all federal elections. 17 Stat. 28 (1872), 2 U.S.C. \& 7 (1958) (House of Representatives) ; 38 Stat. 384 (1914), 2 U.S.C. $\$ 1$ (1958) (Senate); 3 U.S.C. $\$ 1$ (1948) (President).

2743 Stat. 1070-1074 (1925), 2 U.S.C. $\$ \$ 241-56$ (1958).

28 A senatorial candidate is himited to $\$ 10,000$ expenses for a campaign and a candidate for the House of Representatives to $\$ 2,500$, unless a lesser amount is the allowable maximum under state law. 43 Stat. 1073 (1925), 2 U.S.C. § 248 (1958).

20 Enforcement Act of May 31, 1870, ch. 114, § 4, Rev. Stat. $\S 5506$ (1875) (repealed by Act of Feb. 8, 1894, ch. 25, 28 Stat. 36 (1894)).

30 Enforcement Act of May 31, 1870, ch. 114, §§ 19-20, Rev. Stat. §§5511-12 (1875) (repealed by Act. of Feb. 8, 1894, ch. 25, 28 Stat. 36 (1894)).

31 Enforcment Act of April 20, 1871, ch. 22, § 2, Rev. Stat. $\$ 5520$ (1875) (repealed by Act of Feb. 8, 1894, ch. 25, 28 Stat. 36 (1894)).

32 Enforcement Act of May 31, 1870, ch. 114, §§ 2-3, 20, Rev. Stat. \$\$ 2005-07, 5515 (1875) (repealed by Act of Feb. 8, 1894, ch. 25, 28 Stat. 36 (1894)). For convictions under these statutes see In re Coy, 127 U.S. 731 (1888) (failure to turn over ballots to county clerk); United States v. Gale, 109 U.S. 65 (1883) (stuffing ballot box). A charge of altering the tally for local offices only was held to be insufficient under these statutes in Ex parte Perkins, 29 Fed. 900 (C.C.D. Ind. 1887).

33 Enforcement Act of Feb. 28, 1871, ch. 99, Rev. Stat. $\S \S 2011-31$ (1875) (repealed by Act of Feb. 8, 1894, ch. 25, 28 Stat. 36 (1894)). 
ber of citizens to the local circuit court, the court was authorized to appoint supervisors for the election and the preceding registration period. These supervisors were to challenge any unqualified person offering to register, while causing to be registered any applicant possessing the necessary qualifications. ${ }^{34}$ The supervisors were to be present to insure that only qualified voters participated in the balloting and to guarantee that the ballots were fairly counted. ${ }^{35}$

This system was held to be a vahid exercise of congressional authority. ${ }^{30}$ However, it was repealed in $1894,{ }^{37}$ thus returning to the states the primary responsibility for the protection and conduct of elections, a responsibility they had borne prior to the Civil War ${ }^{38}$ After this repeal, there remained in effect civil and criminal statutes protecting constitutional rights in general, which were applied to protect the right to vote. ${ }^{39}$

Although the legislation based upon article I has been far reaching, in none of it has Congress endeavored to regulate the actual qualifications of voters. Even the supervisor system left this to the states, and attempted instead to insure that registration and voting would be conducted impartially. Nor would the authority

34 The supervisors were to sign each page of the registration list and to take other steps they felt necessary to expose the improper removal from or addition thereto of any name. Rev. Stat. \& 2016 (1875).

35 This writer was unable to determine the extent to which the supervisor system was utilized. There are only two reported cases involving it, see note 36 infra. The historical studies of the reconstruction era give no indication of how widespread its use was, although several works do mention it. See Alien, Reconstruction 187 (1937); Carter, The Angry Scar 162 (1959).

36 In Ex parte Siebold, 100 U.S. 371, (1879) a conviction was upheld under Rev. Stat. $\S \S 5515,5522$ (1875) charging an election official with interfering with the appointed supervisors. The plan was also held to be constitutional in In re Supervisors of Election, 23 Fed. Cas. 430 (No. 13628) (C.C.D. Ohio 1878).

3728 Stat. 36-37 (1894). More of these statutes were repealed by 35 Stat. 1153 (1909).

38 "Let every trace of the reconstruction measures be wiped from the statute books; let the States of this great Union understand that the elections are in their own hands, and if there be fraud, coercion, or force used they will be the first to feel it." H. Rep. No. 18, 53d Cong., 1st Sess. (1894), quoted by Justice Douglas in dissent, United States v. Classic, 313 U.S. 299, 335 (1941).

${ }^{39}$ The present 18 U.S.C. $\S 241$ (1948) prohibits conspiracies to threaten any citizen in the free exercise or enjoyment of any right or privilege secured by the Constitution or laws of the United States. For recent cases involving voting see Fields v. United States, 228 F.2d 544 (4th Cir. 1955) (mailing fraudulent ballots); Crolich v. United States, 196 F.2d 897 (5th Cir. 1952) (casting false ballots) ; Prichard v. United States, 181 F.2d 326 (6th Cir. 1950) (stuffing ballot box); Klein v. Umited States, 176 F.2d 184 (8th Cir. 1949) (allowing unqualified voters to vote); Ledford v. United States, 155 F.2d 574 (6th Cir. 1946) (tampering with ballots).

For cases involving precursors of $\$ 241$ see United States v. Mosley, 238 U.S. 383 (1915) (election official convicted for fraudulently miscounting ballots in a congressional election); Ex parte Yarbrough, 110 U.S. 651 (1884) (conviction upheld for the beating of a Negro to prevent hrm from voting for a member of Congress).

The present 18 U.S.C. $\S 242$ (1948) punishes those acting under color of law who subject any person to a deprivation of any right or privilege secured by the Constitution or laws of the United States. The precursor of this statute was applied in United States v. Saylor, 322 U.S. 385 (1944) (stuffing ballot box), and United States v. Classic, 313 U.S. 299 (1941) (altering of ballots).

For similarly worded civil statutes see 17 Stat. 13 (1871), 42 U.S.C. $\$ \S 1983,1985$, applied in Smith v. Allwright, 321 U.S. 649 (1944) (preventing Negro from participating in primary election); Lane v. Wilson, 307 U.S. 268 (1939) (enforcement of racially discriminatory voting statute); Myers v. Anderson, 238 U.S. 368 (1915) (enforcement of "grandfather" clause); Chapman v. King, 154 F.2d 460 (5th Cir. 1946) (preventing Negro from participating in primary election). 
of section 4 to regulate the "manner" of holding elections seem capable of being stretched to encompass the fixing of qualifications, particularly when read in conjunction with article I, section 2. Its scope is limited to the procedural aspects of the electoral process and does not include the substantive determination of who may participate in that process.

If the proposed legislation is characterized as a regulation of qualifications it cannot stand, for the prescription of qualifications lies with the states. It is arguable, however, that its purpose is to protect the constitutional right to vote in congressional elections. Congress may use any "necessary and proper" means to insure that those individuals who qualify under state law receive the opportunity to register and to vote. ${ }^{40}$ The determination of whether the present legislation is a proper manner of achieving this goal is comparable to that which must be made in deciding whether the legislation is an appropriate means of accomplishing the ends of the fifteenth amendment. Therefore, the question will be considered in conjunction with the discussion of the fifteenth amendment.

\section{B. Presidential Elections}

The congressional authority to regulate presidential elections springs from a different source from that for congressional elections. The method for the selection of presidential electors is prescribed by article II: "Each State shall appoint, in such a manner as the Legislature thereof may direct, a number of electors, equal to the whole number of Senators and Representatives to which the State may be entitled in the Congress...." "4I

This leaves to the state legislatures the choice between direct appointment, popular elections, or any other manner of selection. ${ }^{42}$ If an election is held, it may be restricted in any way not otherwise in conflict with the Constitution. Thus, it is allowable for a state to hold the election by districts rather than on a statewide basis. ${ }^{43}$ Congress also lacks the general authority to control the time, place, and manner of conducting presidential elections. It is limited to designating the day on which the electors are to be chosen and the day on which the electors shall cast their votes. ${ }^{44}$

Because of the lack of direct constitutional authorization, the Supreme Court has been forced to fall back upon the inherent powers of Congress to uphold legislation regulating the conduct of presidential elections. The holding in Burroughs E. Cannon v. United States, ${ }^{45}$ marks the furthest the Court has gone in sanctioning such legislation. In that case the defendants were charged with violating the Federal Corrupt Practices Act ${ }^{46}$ for failing to file reports on contributions received by

40 United States v. Classic, 313 U.S. 299, 315 (1941) ; Swafford v. Templeton, 185 U.S. 487, 491 (1902); Wiley v. Sinkler, 179 U.S. 58, 62-63 (1900) ; Ex parte Yarbrough, 110 U.S. 651, 661 (1884).

41 U.S. Const. art. II, $\S 1$. The electors meet in their respective states and cast their ballots for the President and Vice President. The tally is then sent to the President of the Senate, who counts the votes in the presence of both houses of Congress. U.S. ConsT. amend. XII.

42 "The Constitution does not provide that the appointment of electors shall be by popular vote ...." McPherson v. Blacker, 146 U.S. 1, 27 (1892).

43 McPherson v. Blacker, 146 U.S. 1 (1892).

44 "The Congress may determine the time of choosing the electors, and the day on which they shall give their votes; which day shall be the same throughout the United States." U.S. Const. art. $\Pi, \S 1$.

45290 U.S. 534 (1934).

40 See note 27 supra. 
a political committee formed to influence the election of presidential electors in two or more states. The defendants contended the authority of Congress was limited to determining the tine for the choosing of electors. The Court replied:

To say that Congress is without power to pass appropriate legislation to safeguard such an election from the improper use of money to influence the result is to deny the nation in a vital particular the power of self protection. Congress, undoubtedly, possesses that power, as it possesses every other power essential to preserve the departments and institutions of the general government from impairment or destruction, wbether threatened by force or by corruption. 47

It is doubtful, however, whether this inherent power would be lield to permit Congress to establish the voting qualifications for presidential elections. This would be a step once removed from the protection of the voter from force or fraud after he has been qualified by the state. However, by characterizing the two bills as measures necessary to prevent eligible registrants from being defrauded of the right to vote, they might be sustainable in so far as they relate to presidential elections. Once again the test would be whether they are proper means of protecting these elections.

\section{The Fourteenth Amendment}

The first and fifth sections of the fourteenth amendment empower Congress to take appropriate steps to: (1) Prevent any abridgement by the states of the privileges and immunities of national citizenship; (2) prevent the states from taking life, liberty or property without due process of law; and (3) prevent the states from denying to any person the equal protection of its laws.

In Minor v. Happersett, when discussing the fourteenth amendment, the Supreme Court stated: "The amendment did not add to the privileges and immunities of a citizen. It simply furnished an additional guaranty for the protection of such as he already had." ${ }^{48}$ This statement is correct since the fourteenth amendment does not by itself make suffrage one of the rights of national citizenship. This was decisive of the case before the Court, in which a woman was contending that the privileges and immunities clause invalidated Missouri's restriction of the franclise to males. However, as later cases have pointed out, ${ }^{40}$ the right to vote for members of Congress is a constitutional right, once the states have prescribed the qualifications. Further, national citizenship imcludes the right to vote free from discrimination on account of race or color ${ }^{50}$ or sex. ${ }^{51}$ On the other hand, the privileges and immunities clause grants no substantive right greater than that bestowed by article $I$ and the fifteenth amendment, so that by itself it is of no assistance in endeavoring to validate the proposed legislation.

47250 U.S. 534,545 (1934).

4888 U.S. 162, 171 (1875). See also Pope v. Williams, 193 U.S. 621,632 (1904); United States v. Cruikshank, 92 U.S. 542, 555 (1875); United States v. Miller, 107 Fed. 913, 914 (D. Ind. 1901).

49 United States v. Classic, 313 U.S. 299, 315 (1941); Swafford v. Templeton, 185 U.S. 487, 491 (1902); Wiley v. SinkJer, 179 U.S. 58, 62-63 (1900); Ex parte Yarbrough, 110 U.S. 651, 663-64 (1884).

50 See note 77 infra.

51 Although there are no Supreme Court cases in point, decisions in state courts have established that the nineteenth amendment does not grant the right to vote, but rather grants the right to be free from discrimination on account of sex, just as the fifteenth amendment grants the right to be free from discrimination on account of race or color. See, e.g., Graves v. Eubank, 205 Ala. 174, 87 So. 587 (1921); Prewitt v. Wilson, 242 Ky. 231, 46 S.W.2d 90 (1932); State v. Mittle, 120 S.C. 526, 113 S.E. 335 (1922); Glover v. Cobb, 123 S.W.2d 794 (Tex. Civ. App. 1938). 
The due process clause is of no significance in securing the right to vote, although it has been said that once the franchise has been granted to an individual it may not be taken away by the state without due process of law. .22

The equal protection clause is often used by the courts to invalidate state laws or practices unequally and unreasonably affecting certain classes. Prior to its enactment the states could make arbitrary and even whimsical classifications. ${ }^{53}$ Following its enactment, the refusal by a state to allow Negroes to participate in a primary election was held to violate its command. ${ }^{54}$ The clause also prohibits the discriminatory application of otherwise vahid laws. Thus, although a literacy or understanding test may be an appropriate qualification requirement, ${ }^{55}$ its discriminatory enforcement would be grounds for its nullification. ${ }^{56}$ The equal protection clause, however, has not often been used as the basis for affirmative voting legislation. ${ }^{57}$ Its usefulness in sustaining the proposed restrictions on literacy tests is quite limited since the fifteenth amendment covers approximately the same ground.

The equal protection clause is important, however, in considering the first definition of a deprivation of the right to vote contained in the Administration's bill, viz., the application to any person of a more stringent standard or procedure than is applied to others similarly situated. ${ }^{58}$ This apears to be a rephrasing of the equal protection clause, and would encoinpass those state activities that now come under its ban. The enactment of this portion of the bill would assist the Attorney General in the prosecution of suits to enjoin discriminatory voting practices. At present, in suits brought against registrars by the Attorney General ${ }^{59}$ he must prove that the difference in treatment accorded to Negroes was the result of their race. Under the proposed bill, in the identical circumstances, the Attorney General would only need to establish that the Negroes were treated differently from other registrants by the state officials. This section of the amendment would also allow the Attorney General to bring suit in instances where the discrimination practiced is motivated by other than racial feelings.

The second section of the fourteenth amendment remains to be considered. The section reads:

Representatives shall be apportioned among the several States according to their respective numbers .... But when the right to vote at any election for the choice of electors for President and Vice President of the United States, Representatives in Congress, the Executive and Judicial officers of a State, or the members of the Legislature thereof, is destied to any of the male inhabitants of such State, being twenty-one years of age, and citizens of the United States, or in any way abridged, except for participa-

52 Minor v. Happersett, 88 U.S. 162, 176 (1875).

53 Previously, "it was within the power of the state to exclude citizens of the United States from voting on account of race, age, property, education, or on any other ground however arbitrary or whimsical." United States v. Miller, 107 Fed. 913, 915 (D. Ind. 1901). See also United States v. Reese, 92 U.S. 214, 217-18 (1875).

54 Nixon v. Herndon, 273 U.S. 536 (1927).

55 Lassiter v. Northampton Election Bd., 360 U.S. 45 (1959); Guinn v. United States, 238 U.S. 347, 366 (1915); Williams v. Mississippi, 170 U.S. 213, 221 (1898); Trudeau v. Barnes, 65 F.2d 563, 564 (5th Cir. 1933).

50 Lassiter v. Northampton Election Bd., 360 U.S. 45, 50 (1959); Williams v. Mississippi, 170 U.S. 213, 223-25 (1898).

57 In United States v. Harris, 106 U.S. 629 (1883), Rev. Stat. 5519 (1875) was held to be unconstitutional for not limiting its applicability to actions by a state. This statute penalized any conspiracy to deprive any person of the equal protection of the laws.

58 S. 2750, 87th Cong., 2d Sess. $\$ 2$ (1962).

50 This was authorized by the provisions of the 1957 Civil Rights Act, see note 8 supra. 
tion in rebellion, or other crime, the basis of refresentation therein shall be reduced in the proportion which the number of such male citizens shall bear to the number of male citizens twenty-one years of age in such State. (Emphasis added.)

At the time of its enactment this section was considered by some Congressmen to be of far greater import than the first section. ${ }^{60}$ It was designed to induce the Southern States to grant suffrage to the freedmen, under pain of suffering a reduction in their congressional representation for failure to do so. ${ }^{01}$ The first drafts of this section debated in Congress called for a reduction only where the abridgement or denial of the right to vote occurred because of race or color ${ }^{62}$ The section as adopted is not so limited and authorizes a reduction in a state's basis of representation when it imposes restrictions of any type. A state's literacy test or property requirement and possibly even its residence requirements ${ }^{63}$ would be grounds for reducing that state's basis of representation in Congress.

In spite of the potential effectiveness of this section in securing the right to vote, ${ }^{64}$ it has never been used to alter a congressional apportionment. Only once in a federal court has an apportionment been directly challenged ${ }^{65}$ on the basis of section 2. There, the plaintiff sought damages from the Secretary of State of Vir-

60 For the legislative background of this section see Zuckerman, A Consideration of the History and Present Status of Section 2 of the Fourteenth Amendment, 30 FORDHAM L. REV. 93, 93-116 (1961); Bonfield, The Right to Vote and Judicial Enforcement of Section Two of the Fourteenth Amendment, 46 CORNELI. L.Q. 108, 108-21 (1960).

61 See ALLEN, Reconstruction 85 (1937); Zuckerman, supra note 60, at 102; Bonfield, supra note 60 , at 111 .

62 "Representatives and direct taxes shall be apportioned among the several States which may be included within this Union, according to their respective numbers, counting the whole number of citizens in the United States in each State; provided that, whenever the elective franchise shall be denied or abridged in any State on account of race, creed or color, all persons of such race, creed or color, shall be excluded from the basis of representation." KENDRICK, THE Journat of THE JoINT CoMartitee of FIFTEEN ON ReConstruction 50-51 (1914). This resolution was approved with amendinents by the powerful joint committee. However, after passing the House it failed to win the required two-thirds approval of the Senate. The joint committee then redrafted the section in substantially the terms as it now stands.

63 The term "imhabitants" could be interpreted to allow residence requirements. See Bonfield, supra note 60 , at 116, where the author sets forth his view that inhabitancy is a word of art having an independent federal meaning that can be used to judge all state residency requirements.

64 By comparing the state percentage of voting participation in the 1952 election with the national average, one writer has calculated the following penalties were $\S 2$ enforced:

$\begin{array}{lccc}\text { State } & \begin{array}{c}\text { Number of } \\ \text { Representatives }\end{array} & \text { Penalty } & \begin{array}{c}\text { Penalty with } \\ \text { 10\% leeway }\end{array} \\ \text { Alabama } & 9 & 4 & 3 \\ \text { Arkansas } & 6 & 2 & 1 \\ \text { Georgia } & 10 & 3 & 2 \\ \text { Kentucky } & 8 & 1 & 0 \\ \text { Louisiana } & 8 & 2 & 1 \\ \text { Mississippi } & 6 & 2 & 2 \\ \text { North Carolina } & 12 & 1 & 0 \\ \text { South Carolina } & 6 & 2 & 2 \\ \text { Tennessee } & 9 & 2 & 1 \\ \text { Texas } & 22 & 4 & 2 \\ \text { Virginia } & 10 & 3 & 2\end{array}$

Bonficld, sttpra note 60 , at 137 .

65 In Dennis v. United States, 171 F.2d 986 (D.C. Cir. 1948), af'd on other grounds, 339 U.S. 162 (1950), the defendant was convicted for willfully failing to respond to a subpoena issued by the House Un-American Activities Committee. Petitioner's defense was that the committee was not validly constituted so long as John E. Rankin of Mississippi sat on it, for Mis- 
ginia. He based the action on the official's failure to certify him as a candidate for Representative-at-large to the House of Representatives, a position that the Secretary said did not exist. ${ }^{68}$ Plaintiff's theory was that the Virginia poll tax abridged the right to vote of sixty per cent of its citizen-inhabitants over twenty-one, resulting, by virtue of section 2, in a reduction of Virginia's representation from nine to four. With such a reduction and a failure of the legislature to reapportion the state, all representatives would be elected at large. ${ }^{67}$ The dismissal by the district court was affirmed by the Fourth Circuit because the complaint presented a political question not proper for judicial determination. ${ }^{68}$

The Supreme Court has made known its views on section 2 only fleetingly and in dicta. In 1959 in Lassiter v. Northampton Election Bd. ${ }^{69}$ the Court reiterated its previously taken position that the right to vote in section 2 "refers to the right to vote as established by the laws and constitution of the State."70 This means that the section is inoperative until qualified citizens ${ }^{71}$ are denied the right to registered or to vote. Althougl this appears to be incorrect historically, ${ }^{\mathbf{7 2}}$ it remains as the only expression by the Court concerning section 2 .

Even assuming the Court was to accept the view that section 2 does apply to all voting qualifications except those explicitly excepted, this would not authorize congressional activity of the type contemplated by the bills under discussion. The section does not prohibit a state from denying the right to vote to any of its citizeninhabitants, but rather calls for a reduction in the state's representation if it chooses so to act. A restriction upon the qualifications a state may impose designed to make such a reduction unnecessary, as is envisioned by the present proposals, does not come within the ambit of section $2 .^{\mathbf{7 3}}$

\section{The Fifteenth Amendment}

Although the bills may in part be supported by other constitutional powers, it is upon the fifteenth amendment that they must stand or fall. The fifteenth amend-

sissippi was entitled to four rather than seven representatives under the proper application of $\S 2$. The court called this "slieer nonsense" approaching the "fantastic." 171 F.2d at 992-93. The court stressed that the duty to effectuate the provisions of $\$ 2$ lay with Congress and not with the courts. 171 F.2d at 993.

66 Saunders v. Wilkins, 152 F.2d 235 (4th Cir. 1945). For a discussion of the case see 32 VA. L. REv. 647 (1946).

B7 It is provided by statute, 55 Stat. 761 (1941), 2 U.S.C. $\$ 2 \mathrm{a}$ (1958), that until a state redistricts following a congressional reapportionment: (1) if there is no change in the number of representatives the previous districts shall be used; (2) if there is an increase, the new representatives shall be elected at large; or (3) if there is a decrease below the number of current districts, then all representatives shall be elected from the state at large.

68 The Supreme Court demied certiorari, 328 U.S. 870 (1946). Justice Douglas voted for granting the petition.

69360 U.S. 45 (1959).

70 Id. at 51, quoting from McPherson v. Blacker, 146 U.S. 1, 39 (1892).

71 Although $\S 2$ applies only to "male inhabitants," it seems that the nineteenth amendment would override this limitation and make it applicable to women as well. See Zuckerman, supra note 60 , at 122 ; Bonfield, supra note 60 , at 115 .

72 See Zuckerman, supra note 60 , at 102-10; Bonfield, supra note 60 , at 112-14.

73 In 1957 and 1959 Senator McNamara (D. Mich.) introduced bills designed to implement $\S 2$. These bills called for the establisliment of a Joint Committee on Congressional Representation which would determine the extent of abridgement of the right to vote in accordance with $\S 2$ and calculate the proper reduction in representation for the guilty states. This determination was to be binding unless within 30 days Congress passed a concurrent resolution disapproving of the committee report. S. 1084, 86th Cong., 1st Sess. (1959); S. 2709, 85th Cong., 1st Sess. (1957). This proposal is discussed in Zuckerman, supra note 60, at 120-24. 
ment declares that "The rights of citizens of the United States to vote shall not be denied or abridged by the United States or by any State on account of race, color, or previous condition of servitude." T4 This amendment was intended to enable the Negro to vote and to allow Congress to protect his exercise of the franchise through any "appropriate legislation." 75

Although the fifteenth amendment does not bestow the right of suffrage upon any person, ${ }^{76}$ it may have this effect indirectly by requiring that the word "white" be striken from any state's voting requirements. Thus, Negroes who otherwise meet the state standards are entitled to register and to vote. The amendment does invest every citizen of the United States with a new constitutional right to be free, when voting, from state discrimination on account of race or color. ${ }^{77}$ The right to vote includes the right to participate in primary elections, ${ }^{78}$ as well as the right to register in a non-discriminatory manner. ${ }^{79}$ The protection given to the registration process is of prime importance, for discrimination here is much easier to practice and to disguise than at the polls.

In this area the fifteenth amendment has been held to invalidate "grandfather" clauses. Under such provisions those citizens whose ancestors were registered on a specified date, when whites only were allowed to vote, were deemed permanently registered. All other citizens were required to submit to registration tests. ${ }^{80}$ The fifteenth amendment also has been held to invalidate laws giving to registrars the power to administer tests completely lacking in standards. ${ }^{81}$ In addition, it prevents the discriminatory application of otherwise non-discriminatory voting statutes. 82

Congress has often legislated to enforce the broad protection given by the amendment to every step of the election process. Some of the legislation enacted shortly after its passage was declared unconstitutional for penalizing discriminations based upon factors other than race or $\operatorname{color}^{83}$ or for encompassing discrimi-

74 U.S. CoNsT. amend. XV, \&1.

75 U.S. Const. amend. XV, § 2.

76 United States v. Reese, 92 U.S. 214, 217 (1875) ; Karem v. United States, 121 Fed. 250, 254 (6th Cir. 1903); United States v. Amsden, 6 Fed. 819, 821 (D. Ind. 1881).

77 United States v. Cruikshank, 92 U.S. 542, 555 (1875); United States v. Rcese, 92 U.S. 214,218 (1875).

78 Nixon v. Herndon, 273 U.S. 536 (1927) (Negroes excluded by state law); Nixon v. Condon, 286 U.S. 73 (1932) (authority to exclude originated with the state); Smith v. Allwright, 321 U.S. 649 (1944) (the decision expressly overruled Grovey v. Townsend, 295 U.S. 45 (1935) where it was held that the Negro complamant had no cause of action for being denied the right to participate in a Democratic party primary that was restricted by the party convention to whites only); Rice v. Elmore, 165 F.2d 387 (4th Cir. 1947) (primary an integral part of the election machimery); Chapman v. King, 154 F.2d 460 (5th Cir. 1946) (primary an integral part of the election machinery). In Terry v. Adams, 345 U.S. 461 (1953), the fiftcenth amendment was held to apply even to a pre-primary election.

70 United States v. Raimes, 362 U.S. 17 (1960).

80 Lane v. Wilson, 307 U.S. 268 (1939); Guinn v. United States, 238 U.S. 347 (1915).

81 Davis v. Schnell, 81 F. Supp. 872 (S.D. Ala. 1949), aff'd per curiam, 336 U.S. 933 (1949).

82 Byrd v. Brice, 104 F. Supp. 442 (W.D. La. 1952). This case involved a discriminatory application of a requirement whereby two registered voters had to "vouch" for the new registrant.

83 In United States v. Reese, 92 U.S. 214 (1875), $\$ 3$ and $\$ 4$ of the Enforcement Act of 1870 (16 Stat. 140 (1870)) were struck down. Section 3 deemed as performed any prerequisite to voting offered to be performed by a citizen when a wrongful act or omission by a state official was responsible for the failure of the execution of the prerequisite. Section 4 penalized any person for bribing or threatening another from voting or from doing any act necessary to qualify to vote. 
nations practiced by individuals as well as by states. ${ }^{84}$ In these cases it was the ends, and not the means utilized by Congress, that the Court found objectionable.

Many of the measures passed sliortly after the adoption of the fifteenth amendment were repealed in 1894 . Only the general statutes previously mentioned were retained, as was the present 42 U.S.C. section 1971 (a), which grants to all qualified citizens the riglit to vote in both state and federal elections without distinction as to race or color. In 1957 Congress empowered the Attorney General ${ }^{85}$ to seek injunctive relief when there is a violation of either 42 U.S.C. section 1971 subsection (a), or subsection (b), which prohibits both private individuals and states from interfering with the right of any person to vote in federal elections. In a suit brought against state registrars for engaging in racial discrimination in violation of subsection (a), the Supreme Court held that the legislation allowing such suits by the Attorney General was appropriate under the fifteenth amendment. ${ }^{80}$

In 1960 the referee plan was added. ${ }^{87}$ Under this plan the Attorney General first brings a suit under the 1957 Civil Riglits Act seeking to enforce the riglit guaranteed by subsection (a). If successful, he inay request from the court a finding that the deprivations of the right to vote in the instant suit were pursuant to a pattern or practice of racial discrimination. If such a finding is made, the court may appoint voting referees to investigate the qualifications of applicants who are of the same race or color as the original complainant, and who assert either that they have been denied the right to register or that they have been found not qualified to register. If the referee determines the applicant is qualified under state law, he transmits his finding to the court, where the state may cliallenge it. If the challenge is resolved in favor of the applicant, or if there is no challenge, the applicant is given a certificate attesting to lis qualifications for both state and federal elections.

To date the constitutionahty of the referee plan has only been considered by a three judge district court. ${ }^{88}$ In this case the defendants, both individuals and the local Citizens Councils, contended that the referee plan could not be set into operation as the result of their private acts, since the prolibition of the fifteenth amendment applies only to states. The court found that the defendants' behavior was in fact "state action" in that it triggered a response by the state registrar.

If this statute is challenged before the Supreme Court it seems certain that its vahdity will be upheld. The fifteenth amendment prohibits state racial discrimination, and the plan is not set in motion until there is a finding of such discrimination. In addition, each prospective registrant must prove either that he las been found unqualified by a state official, which indicates he has been the victim of some manner of discrimination, ${ }^{89}$ or that lie lias been demied the opportunity to register, which under the circumstances of a pattern or practice of racial discrimination at

${ }^{84}$ In James v. Bowman, 190 U.S. 127 (1903), $\$ 5$ of the Enforcement Act was challenged. It prohibited the intimidation of another by bribery or threats to prevent his exercise of the right of suffrage as guaranteed by the fifteenth amendment. This section was also held to be unconstitutional in Lackey v. United States, 107 Fed. 114 (6th Cir. 1901); United States v. Miller, 107 Fed. 913 (D.Ind. 1901); United States v. Amsden, 6 Fed. 819 (D. Ind. 1881).

85 See note 8 sitpra.

86 United States v. Raines, 362 U.S. 17 (1960). Accord, United States v. Thomas, 362 U.S. 58 (1960); In re Wallace, 170 F. Supp. 63 (M.D. Ala. 1959).

8774 Stat. 90 (1960), 42 U.S.C. \$ 1971 (e) (1960).

88 United States v. Association of Citizens Councils, 187 F. Supp. 846 (W.D. La. 1960).

89 The equal protection clause would here operate in support of the legislation, regardless of the motivation for the discrimination. 
least raises an inference of discrimination. Although there might be instances where a person who has not been the victim of racial discrimination could register with a referee, the plan appears to be sufficiently related to the prevention of racial discrimination to be "appropriate" under the fifteenth amendment.

Turning to the validity under the fifteenth amendment of the two bills presently before Congress, it may be tentatively concluded that they are constitutional, although it is true that if enacted they would in many instances prevent the states from discriminating upon the basis of education or intelligence. This type of state discrimination was recently upheld by the Supreme Court in Lassiter v. Northampton Election Bd.90 There the plaintiff challenged the North Carolina law requiring all prospective voters be able to read and write any section of the state constitution in English. In rejecting the challenge the Court remarked:

The States have long been held to have broad powers to determine the conditions under which the right of suffrage may be exercised .... We do not suggest that any standard which a State desires to adopt may be required of voters. But there is wide scope for exercise of its jurisdiction. 91

The enactment of either bill would greatly affect the enforcement of literacy tests, and would increasingly do so as the level of education continues to rise. ${ }^{92}$

90360 U.S. 45 (1959).

91 Id. at $50-51$.

92 At present there are many people in this country who have not completed six years of schooling, and the percentage figure is higher in the south than elsewhere. The median number of years completed, however, has been rising. In Table I below, the total population over the age of 25 in each of the listed states is given, followed by the figures on the number of school years completed and the median number of years completed for both 1950 and 1960 . The comparable figures for the nonwhite population in these states is given in Table II.

TABLE I

TOTAL STATE FIGURES

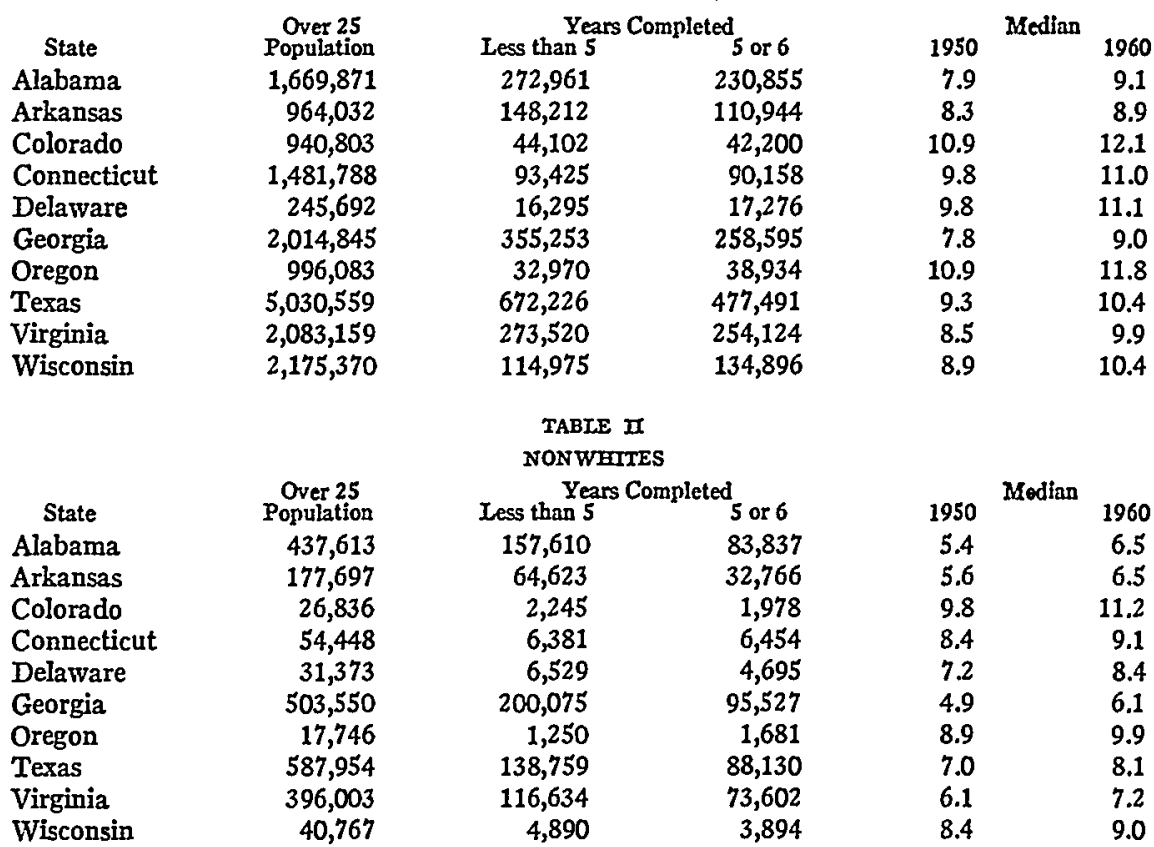

Source: United States Census of Population: 1960 "C" Series. 
Although Congress has no power to impinge upon the application of these tests as literacy tests, it may use appropriate means to prevent the racially discriminatory application of such tests. Even though the legislation would in effect forbid some state actions not in themselves racially discriminatory, this does not necessarily mean it is inappropriate. Often the Supreme Court has upheld legislation that prohibited actions which, standing alone, were outside the power of the legislature, providing the enactments were necessary to achieve a valid legislative goal. In United States v. Darby ${ }^{93}$ the Court upheld the original Fair Labor Standards Act as being within the congressional power over interstate commerce. The Act forbade the interstate transfer of goods manufactured under sub-standard labor conditions. This entailed a great deal of regulation over purely intrastate activity. In the course of its opinion the Court stated:

\begin{abstract}
Congress, having by the present Act adopted the policy of excluding from interstate commerce all goods produced for the commerce which do not conform to the specified labor standards, it may clroose the means reasonably adapted to the attainment of that permitted end, even though they involve control of intrastate activities. Such legislation has often been sustained with respect to powers, other than the commerce power granted to the national government, when the means chosen, although not themselves within the granted power, were nevertheless deemed appropriate aids to the accomplisliment of some purpose within an admitted power of the national government.94
\end{abstract}

The Court often utilized this so-called "penumbra" doctrme ${ }^{05}$ in dealing with legislation implementing Prohibition. In question was Congress' power to prevent the inanufacture or sale of non-intoxicating malt or liquors as an incident of its authority to halt the sale and manufacture of intoxicating liquors. Uniformly the Supreme Court held such legislation to be valid. ${ }^{96}$ In these cases the Court relied heavily on prior applications of the penumbra doctrine to state legislation. In one such case the Court said:

It is also well established that, when a State exerting its recognized authority undertakes to suppress what it is free to regard as a public evil, it may adopt such measures having reasonable relation to that end as it may deem necessary in order to make its action effective. It does not follow that because a transaction separately considered is innocuous it may not be included in a prohibition the scope of whicli is regarded as essential in the legislative judgment to accomplish a purpose within the admitted powers of the Government.97

Although the issue in these cases where the state's relationship to the individual is concerned is not identical with that where the division of authority between the state and federal governments is involved, it is substantially similar. In both types of cases the Court has nuet the argument that the legislation affected some inno-

93312 U.S. 100 (1941).

94 Id. at 121 .

95 "Of course many gifts will be hit by the tax that were made with no contemplation of death. But the law allows a penumbra to be embraced that goes beyond the outline of its object in order that the object inay be secured." Justice Holmes in dissent, Schlesinger v. Wisconsin, 270 U.S. 230, 241 (1926).

06 Everard's Breweries v. Day, 265 U.S. 545 (1924); Jacob Ruppert v. Caffey, 251 U.S. 264 (1920); Hamilton v. Kentucky Distilleries Co., 251 U.S. 146 (1919). See also Westfall v. United States, 274 U.S. 256 (1927) (Congress may punish the misapphication of funds in a state bank even though no loss results to the Federal Reserve Banks) ; Thornton v. United States, 271 U.S. 414 (1926) (Congress may require the inspection and treatment of all cattle over an extensive area to prevent the interstate shipment of any of these cattle without treatment).

97 Purity Extract Co. v. Lynch, 226 U.S. 192, 201 (1912). 
cent activity or some activity beyond the scope of legislative control by replying that as long as there is a valid legislative goal, such an inclusion will not by itself be cause for invalidation of the statute. The means used by Congress or a state legislature will only be rejected when they pass "the bounds of reason and assume the character of a merely arbitrary fiat." 98

The problem, therefore, is whether the substantial elimination of literacy tests from the list of allowable qualifications a state may impose is within the justifiable means of accomplishing the ends of the fifteenth amendment. There is ample evidence indicating that literacy tests are in fact used by the states to discriminate on account of race or color. ${ }^{09}$ The Civil Rights Commission found that the arbitrary application of literacy tests and other registration procedures was the major cause of disenfranchisement of Negroes in the South. ${ }^{100}$ In addition, the inclusion within the bills of congressional findings of both the extensive use of such examina tions to deny the right to vote and the adequacy of a sixth grade education to meet literacy requirements would undoubtedly carry great weight with the Court. ${ }^{101}$

Even with this evidence, the Court would have to be satisfied that the legislation was an "appropriate" means of dealing with such discrimination. The penumbra cases would here appear to be persuasive. To effectively achieve the goal clearly within its power, Congress could find it necessary to forbid the use of literacy tests completely where the applicant has completed the sixth grade. Such a step would not appear to pass the "bounds of reason." By this reasoning the proposed bills would certainly seem to be "appropriate legislation" under the fifteenth amendment.

This conclusion applies equally to either bill. The fifteenth amendment forbids any abridgement by the states of the right to vote on account of race, color, or previous condition of servitude. So long as there is state action, which there clearly is with the enforcement of literacy tests, it does not matter what kind of election is involved. Thus, there is no reason to limit the effect of the legislation to federal elections. Indeed, such a limitation would unnecessarily invite the states to go to the added expense of establishing two separate registration procedures, one for state and one for federal elections. Such a reaction by the states would endanger the potential benefit that might be reaped from this type of legislation. Senate Bill 480 avoids this possibility.

As the fifteenth amendment seemingly validates this legislation for all elections, the need to rely upon other constitutional powers is obviated. Nevertheless, it would appear that article I powers and the inherent power to protect presidential elections might also sustain this legislation. The test is whether the means used are proper, and this test will probably yield the same result as that of appropriateness.

98 Purity Extract Co. v. Lynch, 226 U.S. 192, 204 (1912). In Shelton v. Tucker, 364 U.S. 488 n. 8 (1960), the Court indicated in a footnote that these "penumbra" cases could not be applied when a statute impinging upon personal liberties was involved. In the case an Arkansas statute requiring schoolteachers to hist all their organizational associations of the past five years was successfully challenged. This limitation would not apply to the bills under consideration, since they curtail the states' power to control qualifications and do not restrict the frecdom of the individual. (1949).

${ }^{99}$ See Davis v. Schnell, 81 F.Supp. 872 (S.D. Ala, 1949), aff'd per curiam, 336 U.S. 933

1001961 CivII Rights Report 133.

101 Cf. Conımunist Party of the United States v. Subversive Activities Control Bd., 367 U.S. 1, 68-69, 82-86, 112 (1961). 
This legislation would thus seem to be a proper means of insuring both that qualified citizens are able to exercise their constitutional right to vote for congressional offices and that presidential elections remaim free from corrupt influences. Although the final determination of appropriateness or propriety must be made by the Supreme Court, this writer believes the Court would be willing to accept such legislation if enacted by Congress.

\section{III}

\section{EVALUATION}

Although both bills appear to be constitutional, it is doubtful whether either would be of great assistance in eradicating the continuing practice of racial discrimination in voting. ${ }^{102}$ At present if a state does discriminate in the application of its literacy or understanding test, the Attorney General may seek injunctive relief in accordance with the 1957 Civil Rights Act. ${ }^{103}$ In this suit the Attorney General must prove that the Negroes applying to the registrar exhibited the requisite understanding or ability to read and were found unqualified because of their race. With the new legislation the Attorney General's task would be simplified, since he would only need to show that the applicants satisfactorily produced evidence of the completion of six grades of schooling. Nevertheless, it still seems that intermmable law suits would be necessary to prevent discrimination in even this limited area. ${ }^{10 t}$

Further, even assuming that such legislation was successful in preventing discrimination in the application of literacy or intelligence tests, it would not affect the innumerable other opportunities to discriminate that remain in the overall registration process. Although the legislation could somewhat narrow the confines within which racial discrimination might operate, its value would seem to be slight so long as the registration process continues to be in the hands of those dedicated to preserving the white man's control of the electoral process.

Although this legislation would likely be of limited effectiveness in practice, it will arouse tremendous opposition from most southern members of Congress. Their opposition will undoubtedly be intensified by their legitimate doubts (as well as the doubts of others) as to the constitutionality of the measures. ${ }^{105}$ Since ill-will

102 The Civil Rights Commission lists Alabama, Florida, Georgia, Louisiana, Mississippi, North Carolina, South Carolina, and Tennessee as the states where denials of the right to vote because of race or color continue to exist. Throughout the South, of 5,131,042 nonwhites of voting age, 1,361,944 are registered. 1961 CrvII RuGETs REPORT 22.

10374 Stat. 90 (1960), 42 U.S.C. $\$ 1971$ (c) (Supp. II, 1961).

104 This criticism was leveled against the existing legislation by the Civil Rights Commission:

Although the provisions of the 1957 and 1960 Civil Rights Acts are useful, however, they are necessarily limited means for removing racial discrimination from the franchise. Suits must proceed a single county at a time, and they are time consuming, expensive, and difficult. Broader measures are required if denials of constitutional rights in this area are to be quickly eliminated.

1961 CrVIL RIGHTS REPORT 136.

105 Senator Ervin (D.N.C.), Chairman of the Constitutional Rights Subcommittee of the Senate Judiciary Committee, in an opening stateinent for the subcommittee hearings, said the proposed legislation represented an unconstitutional attempt to deprive the states of their right to determine the qualifications of voters. These views were shared by Senators Talmadge (D. Ga.), Sparkman (D. Ala.), and Hill (D. Ala.). 20 CoNG. Q. 521-22 (1962). 
will be engendered by consideration of any civil rights legislation, those congressinen who are sincerely interested in aiding the Negroes in their struggle for voting equality should work for the enactment of a measure more likely to have positive results in achieving this goal. An example would be a federal registrar plan, such as that proposed by the Civil Rights Commission in $1959^{100}$ and introduced in Congress in various forms in 1960.107 Under these plans, in areas where there is evidence of discrimination, the state statutory qualifications are retained, but the entire registration process for federal elections is placed in the hands of federal officials. This approach avoids the objection voiced to the bills that they regulate only a small segment of the total registration and election procedure. If Congress is to pass civil rights voting legislation intended to aid the Negro, a federal registrar plan seems more worthy of its attention than the present proposals.

Reed H. Bement

106 The Commission's 1959 proposal called for the appointment by the President of federal registrars after a set number of complaints involving denials of voting rights were received, and verified, by the Civil Rights Commission. These registrars were to administer the state qualification tests to applicants who alleged they were deried the riglit to vote on account of race or color and to issue voting certificates to those who qualified, for use in federal elections. REPORT of the UNITEd States Comanission on Civin RIoHTs 139-42 (1959).

107 For a comparison of the Commission's recommendation with several other registrar plans and the eventually enacted referee system see Heyman, Federal Remedies for Voleless Negroes, 48 CaLIF. L. REv. 190, 205-13 (1960). Another possibility would be a constitutional amendment establishing the voting qualifications for federal elections. 